Bolm Inst. oceanogr., S Paulo, 40(1/2):87-91, 1992

\title{
The karyotype of Cathorops sp, a marine catfish from Brazil
}

\author{
Vicente GOMES; PHAN Van Ngan \& Maria José de Arruda Campos Rocha PASSOS
}

Instituto Oceanográfico da Universidade de São Paulo

(Caixa Postal 9075, 01065-970 São Paulo, SP, Brasil)

- Abstract: Cathorops sp has the diploid number of 54 chromosomes. The karyotype comprises $1 \mathrm{~m}+\mathrm{sm}, 6 \mathrm{~m}, 6 \mathrm{sm}$ and 14st pairs. This result is compared with those of other species of Ariidae, mainly Ariopsis felis and Arius dussumieri, found in literature.

- Descriptors: Cytogenetic, Chromosomes, Karyotypes, Marine fishes, Ariidae, Cathorops sp, Cananéia, Brazil.

- Descritores: Citogenética, Cromossomos, Cariótipos, Peixes marinhos, Ariidae, Cathorops sp, Cananéia: SP.

\section{Introduction}

Fishes belonging to the family Ariidae (order Siluriformes), popularly known as marine catfishes, have circumtropical occurrence. They can be found in the sea, estuaries and river mouths. Although the literature related to these fishes is extensive their systematics is highly controversial (Wheeler \& Baddokwaya, 1981; Higushi, 1982) and needs to be revised.

Cytogenetical methods have been used as an aid to solve problems related to systematics and evolution of fishes and other animals. Chromosome information on about 129 species belonging to 13 families of marine and freshwater catfishes is available (Fitzsimons et al., 1988). In relation to the family Ariidae, as far as we know, only five species have been karyotyped, including the one presented in this paper.

The fish employed in this work is often denominated as Cathorops spixii and used to be considered as the only species of the genus recognized along the Brazilian coast (Fig. 1). Recent studies (Taylor \& Menezes, 1978), however, indicate that more than one species are probably being denominated by this name. In spite of the fact that no morphological differences between our specimens were observed, Dr. Naércio A. Menezes (pers. com.) suggested to refer to them as Cathorops sp because of the above mentioned uncertainty of the taxonomy of Cathorops species complex.
For all other ariid species cited in this work the nomenclature of Taylor \& Menezes (op. cit.) and Figueiredo \& Menezes (1978) was employed.

In this paper the karyotype of Cathorops sp is described and compared with those of Ariopsis felis and Arius dussumieri found in the literature.

\section{Material and methods}

Specimens were collected in the estuarine region of Cananéia, São Paulo, Brazil ( $\left.25^{\circ} 01^{\prime} \mathrm{S} ; 47^{\circ} 56^{\prime} \mathrm{W}\right)$ from May 1981 to November 1986. The animals were kept alive in 1000 liters tanks with running sea water until being employed. They were then injected intraperitoneally with $0,2 \mathrm{ml} / 100 \mathrm{~g}$ body weight of $0,5 \%$ colchicine in saline solution, sacrificed 4 to 6 hours later and the kidney was removed for chromosome preparations following the procedures described by LeGrande \& Fitzsimons (1976) with slight modification as described in Gomes et al. (1990). The specimens employed were fixed in formalin $4 \%$ and kept in our laboratory at the Instituto Oceanográfico da Universidade de São Paulo.

The metaphases were photographed, the chromosomes were counted and the karyograms mounted from photographic prints. Estimation of the chromosome size in micrometers was made by measuring two easily identifiable chromosomes of a set in middle metaphase using a micrometric eyepiece placed in microscope Wild M20 and then correlating these measures with all the chromosomes of the same set in a photographic print. 


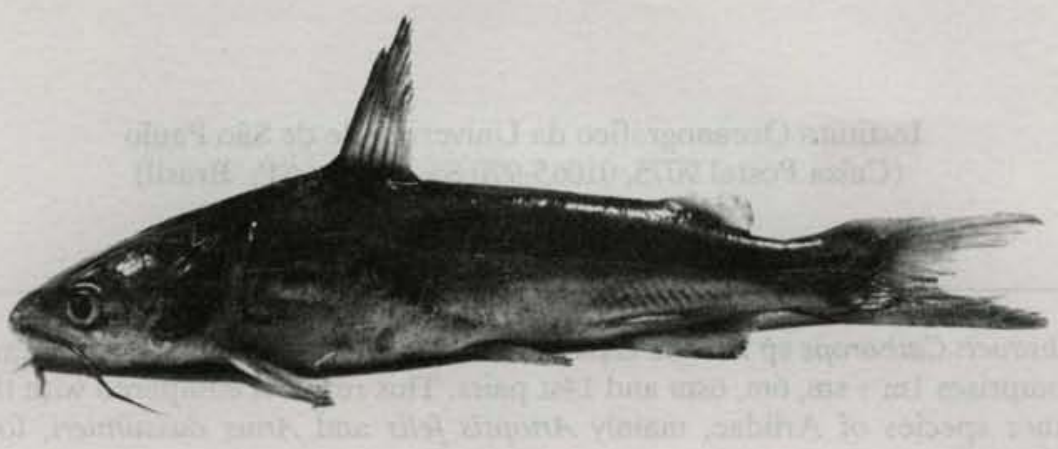

Fig. 1. A specimen of Cathorops sp used in this study. Total length, $174 \mathrm{~mm}$.

The arm ratios (long arm/short arm) were calculated and terminology for centromeric position followed the criteria of Levan et al. (1964). To facilitate the comparisons between our data with other data found in the literature the chromosome types were gathered in groups following Uyeno et al. (1983). Arm numbers (AN) were calculated considering $\mathrm{m}$ (metacentric) and sm (submetacentric) chromosomes as biarmed and st (subtelocentric) as uniarmed.

\section{Results}

Good mitotic metaphase spreads were obtained from 25 specimens of Cathorops sp, 9 males and 16 females, ranging from $150 \mathrm{~mm}$ to $234 \mathrm{~mm}$ in total length.

A total of 257 spreads was examined, 103 for the males and 154 for the females. The cells with diploid number of $2 n=54$ chromosomes account for $87.38 \%$ of the total countings for the males and $83.12 \%$ for the females. The chromosome total length in micrometers taken as an average from 10 selected spreads ranged from $6.29 \mu \mathrm{m}$ to $1.81 \mu \mathrm{m}$.

The two chromosomes of the first pair presented short arms of different sizes detectable in about $60 \%$ of the cells examined. With this heteromorphism it was possible to classify each of them into a distinct type. So, the karyotype consisted of $1 \mathrm{~m}+\mathrm{sm}$ pair, $6 \mathrm{~m}$ pairs, $6 \mathrm{sm}$ pairs and $14 \mathrm{st}$ pairs (Fig. 2). No heteromorphism between males and females was observed.

\section{Discussion}

As described above, the karyotype of Cathorops sp showed a slight morphological difference between the two chromosomes of the first pair noticeable in several cells examined due to the size of the short arms. Variations between chromosomes of a same pair were also observed in other fish species as Lepomis cyanellus (Roberts, 1964) and Hoplias malabaricus (Bertollo, 1978), for example. In Cathorops sp the difference between these two chromosomes of the first pair is more striking at early metaphases, when the chromosomes are still not completely contracted. There are several possibilities that could explain this phenomenon, such as pericentric inversion, heterogeneity in the chromatin condensation during mitosis, etc. It could also be due to an erior resulting from misinterpretation during pairing, but, the distinctness between these two chromosomes and the other chromosomes of $\mathrm{m}$ and $\mathrm{sm}$ types of the complement renders this possibility remote. The possibility that this difference is due to sexual dimorphism can be ruled out since it occurs in both males and females. Artifacts during preparations, although not totally discarded, are also improbable due to the frequency of the heteromorphism observed. At the moment, the origin and significance of the variability in the first chromosome pair of Cathorops sp karyotype remain to be elucidated. Doubteless, the use of some banding methods will be very useful in clarifying this problem.

LeGrande (1981), studying the karyological evolution of Siluriform fishes, suggested that the probable ancestral karyotype of the whole order would be of $2 n=56 \pm 2$; with high AN, i.e., a high proportion of biarmed elements; with the chromosomes gradually decreasing in size and with the biggest chromosome of about $5.0 \%$ of the total size of the complement. This hypothesis has been reinforced by a series of data. For instance, the medium number of chromosomes in the family Bagridae, considered a primitive group within the order, is also of $2 n=56 \pm 2$ (Sharma \& Tripathi, 1986). The five species of Ariidae karyotyped until now, including the one here studied, 


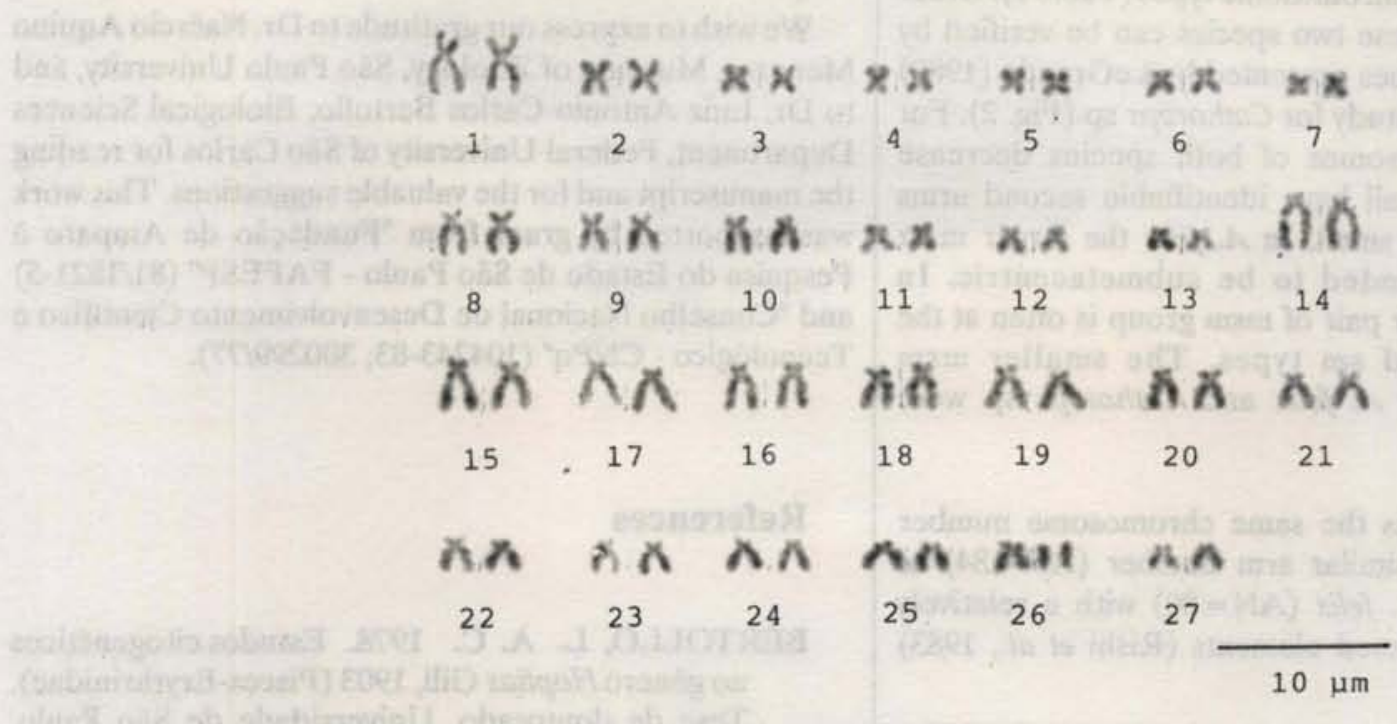

Fig. 2. Karyotype of a male Cathorops sp.

follow the same trend (Table 1). This family is also considered as a group with primitive characteristics among Siluriformes (Gosline, 1975). Among the karyotyped ariids, four species: Ariopsis felis (LeGrande, 1980), Arius dussumieri (Rishi et al., 1983), Bagre marinus (Fitzsimons et al., 1988), Cathorops sp (present study) have $2 \mathrm{n}=54$, and one, Bagre bagre (Gomes et al., 1990), has $2 \mathrm{n}=56$.

The relative size of the biggest chromosome pair of Cathorops sp is on average $6.68 \%$ of total size of the complement, being larger than that expected for the possible ancestral karyotype. This fact suggests that mechanisms which result in changes of chromosome size (such as fusions, translocations, duplications, etc.) could have contributed to the karyological evolution of this species.

Besides these trends in karyological evolution, it is noticeable that the Siluriformes undergone extensive alterations in chromosome morphology during evolution probably due to the high speciation of the order (LeGrande et al., 1984). Karyotypes can be very distinct even among close related species as is the case of the ariids Bagre bagre and B. marinus (Gomes et al., 1990). Nevertheless, when one compares the karyotypes of Cathorops sp and Ariopsis felis some remarkable similarities can be noticed. Both have the same number of chromosome arms $(\mathrm{AN}=80)$ and if $\mathrm{m}$ and $\mathrm{sm}$ chromosomes of Cathorops sp are grouped together as did

Table 1. Karyotypes of some arild catfishes. In parentheses, chromosome types of Cathorops sp grouped together. $\mathrm{m}$, metacentric; msm, meta-submetacentric; sm, submetacentric; st, subtelocentric; stt, subtelo-telocentric

\begin{tabular}{lcccccccc}
\hline \multicolumn{1}{c}{ Species } & 2n & AN & m & msm & sm & st & stt & Reference \\
\hline Bagre marinus & 54 & 74 & 12 & & 8 & & 34 & Fitzsimons et al. (1988) \\
Bagre bagre & 56 & 106 & 24 & & 26 & 6 & & Gomes et al. (1990) \\
Arius dussumieri & 54 & 84 & 12 & & 18 & & 24 & Rishi et al. (1983) \\
Ariopsis felis & 54 & 80 & & 26 & & & 28 & LeGrande (1980) \\
Cathorops sp & 54 & 80 & 13 & $(26)$ & 13 & 28 & $(28)$ & present study \\
\hline
\end{tabular}


LeGrande (1980) for $A$. felis, both species show the same number of msm and stt chromosome types (Table 1). Other similarities between these two species can be verified by comparing the karyotypes presented by LeGrande (1980) for A. felis and by this study for Cathorops sp (Fig. 2). For instance, the chromosomes of both species decrease gradually in size and all have identifiable second arms ranging from large to small. In $A$. felis the larger msm chromosome pair tended to be submetacentric. In Cathorops sp the larger pair of msm group is often at the limit between $\mathrm{m}$ and $\mathrm{sm}$ types. The smaller msm chromosomes of both $A$. felis and Cathorops sp were metacentric.

Arius dussumieri has the same chromosome number $(2 \mathrm{n}=54)$ and also similar arm number $(\mathrm{AN}=84)$ as Cathorops sp and $A$. felis $(\mathrm{AN}=80)$ with a relatively higher number of biarmed elements (Rishi $e t$ al., 1983) (Table 1).

The real meaning of these karyological similarities between the three ariid species belonging to three different genera is difficult to ascertain at the moment. Since many authors agree that the systematics of Ariidae group should be reviewed (Taylor \& Menezes, 1978; Higushi,1982) we believe that citogenetical data could be of great value to the solution of the problem. The systematic positions of the species of the family, however, could only be established after a detailed phylogenetical study using as many characters as necessary.

\section{Conclusion}

The karyotype of Cathorops sp comprises $1 \mathrm{~m}+\mathrm{sm}, 6$ $\mathrm{m}, 6 \mathrm{sm}$ and $14 \mathrm{st}$ pairs of chromosomes. The diploid and arm number are $2 \mathrm{n}=54$ and $\mathrm{AN}=80$ respectively. These features are similar to those of Ariopsis felis and Arius dussumieri described in the literature. The meaning of those similarities is difficult to ascertain at the moment. More citogenetical data could be useful for the systematic of the members of Ariidae family.

\section{Resumo}

Foram realizados estudos cromossômicos em 25 espécimens de Cathorops sp pelo método de air-drying. $\mathrm{O}$ número modal diplóide encontrado foi de 54 cromossomos sendo 1 par $\mathrm{m}+\mathrm{sm}, 6$ pares $\mathrm{m}, 6$ pares sm e 14 pares st. Os resultados são comparados com dados da literatura referentes a cromossomos de outros ariídeos, principalmente de Ariopsis felis e Arius dussumieri.

\section{Acknowledgments}

We wish to express our gratitude to Dr. Naércio Aquino Menezes, Museum of Zoology, Sāo Paulo University, and to Dr. Luiz Antonio Carlos Bertollo, Biological Sciences Department, Federal University of São Carlos for reading the manuscript and for the valuable suggestions. This work was supported by grant from "Fundação de Amparo à Pesquisa do Estado de São Paulo - FAPESP" (81/1821-5) and "Conselho Nacional de Desenvolvimento Científico e Tecnológico - CNPq" (104243-83; 300299/77).

\section{References}

BERTOLLO, L. A. C. 1978. Estudos citogenéticos no gênero Hoplias Gill, 1903 (Pisces-Erythrinidae). Tese de doutorado. Universidade de São Paulo, Faculdade de Medicina de Ribeirão Preto. 164p. + tabs + figs.

FIGUEIREDO, J. L. \& MENEZES, N. A. 1978. Teleostei I. Manual de peixes marinhos do sudeste do Brasil. II. São Paulo, Museu de Zoologia da Universidade de São Paulo. 110p.

FITZSIMONS, J. M.; LEGRANDE, W. H. \& KORTH, J. W. 1988. Karyology of the marine catfish Bagre marinus (Ariidae) with an analysis of chromosome numbers among siluriform fishes. Japan. J. Ichthyol., 35(2):189-193.

GOMES, V.; PHAN, V. N. \& PASSOS, M. J. A. C. R. 1990. Karyotype of a marine catfish, Bagre bagre, from Brazil. Japan. J. Ichthyol., 37(3):321-323.

GOSLINE, W. A. 1975. The palatine-maxillary mechanism in catfishes, with comments on the evolution and zoogeography of modern siluroids. Occ. Pap. Calif. Acad. Sci.,(120):1-31.

HIGUSHI, H. 1982. Estudo osteológico de bagres marinhos do litoral sul do Brasil (Osteichthyes; Silurioidei; Ariidae). Dissertação de mestrado. Universidade de São Paulo, Instituto de Biociências. 135p. + tabs + figs.

LEGRANDE, W. H. 1980. The chromosome complement of Ariopsis felis (Siluriformes, Ariidae). Japan. J. Ichthyol., 27(1):82-84.

1981. Chromosomal evolution in North American catfishes (Siluriformes: Ictaluridae) with particular emphasis of the madtoms Noturus. Copeia, (1):33-52. 
LEGRANDE, W. H.; DUNHAM, R.A. \& SMITHERMAN, R.D. 1984. Karyology of three species of catfishes (Ictaluridae:Ictalunus) and hybrid combinations. Copeia, (4):873-878.

\& FITZSIMONS, J.M. 1976. Karyology of the mullets Mugil curema and $M$. cephalus (Perciformes: Mugilidae) from Louisiana. Copeia, (2):388-391.

LEVAN, A.; FREDGA, K. \& SANDBERG, A.A. 1964. Nomenclature for centromeric position on chromosomes. Hereditas, 52:201-220.

RISHI, K.K.; SINGH, J. \& HAOBAM, M.S. 1983. Karyological study on a marine catfish, Arius dussumieri (Val.) (Ariidae: Siluriformes). Chrom. Inf. Serv., (34):7-9.

ROBERTS, F. L. 1964. A chromosome study of twenty species of Centrarchidae. J. Morphology, 115:401-418.
SHARMA, O.P. \& TRIPATHI, N.K. 1986. Karyotypic diversity in the genus Mystus (Bagridae, Pisces). Cytologia, 51(1):1-9.

TAYLOR, W. R. \& MENEZES, N. A. 1978. Arïdae. In Fischer, W., ed. FAO species identification sheets for fishery purposes. Western Central Atlantic (fishing area 31). Rome, FAO. v.1.

UYENO, T.; MILLER, R. R. \& FITZSIMONS, J. M. 1983. Karyology of the cyprinodontoid fishes of the Mexican family Goodeidae. Copeia, (2):497-510.

WHEELER, A. \& BADDOKWAYA, A. 1981. The generic nomenclature of the marine catfishes usually referred to the genus Arius (Osteichthyes Siluriformes). J. nat. Hist., 15(5):769-773.

(Manuscript received 16 June 1992; revised 23 November 1992; accepted 10 December 1992) 